\title{
Focal osteosclerosis of the skull in primary hyperparathyroidism
}

\author{
Sahana Shetty, Nitin Kapoor, Dukhabandhu Naik, Thomas Vizhalil Paul
}

Christian Medical College, Vellore, Tamil Nadu, India

\section{Correspondence to}

Professor Thomas Vizhalil Paul, thomasvpaul@yahoo.com

Accepted 3 May 2014

\section{DESCRIPTION}

Bony manifestations of hyperparathyroidism are characterised by diffuse osteopenia, brown tumours, subperisoteal bone resorption, pathological fractures, terminal acrosteolysis and salt-and-pepper appearance of the skull, and are secondary to increased resorption. Osteosclerotic changes have been described more often with secondary hyperparathyroidism, especially with renal osteodystrophy, however association with primary hyperparathyroidism (PHPT) has been rarely reported. ${ }^{1}$ We report one such case of focal osteosclerosis with PHPT.

A 23-year-old man presented with right lower limb swelling secondary to a pathological fracture of the distal end of the femur. On evaluation, he was found to have hypercalcaemia, hypophosphataemia,

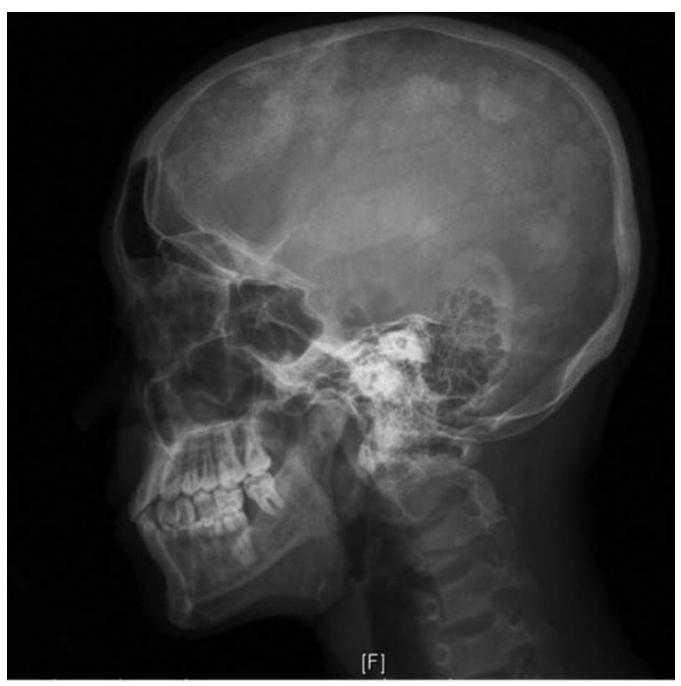

Figure 1 Lateral view of the skull X-ray showing multiple round and oval-shaped osteosclerotic lesions. elevated alkaline phosphatase and hypovitaminosis D. Imaging showed nephrocalcinosis and ureteric calculi. Further evaluation revealed an elevated parathyroid hormone and a low bone mass on dual-energy X-ray absorptiometry (DXA) scan suggestive of PHPT. Localisation studies with an ultrasound of the neck showed lesion in the right superior parathyroid gland with a concordant sestamibi parathyroid scintigraphy (figure 1).

His skeletal survey showed generalised osteopenia and pathological fracture of the right femur. His skull X-ray showed multiple round to oval focal sclerotic changes, which is an unusual radiological presentation in PHPT (figure 2).

The usual radiological features of the skull in PHPT are granular decalcification (salt-and-pepper appearance) and loss of lamina dura of the teeth. Osteosclerosis in hyperparathyroidism may be focal or diffuse. In PHPT, focal sclerotic lesions have been described at times to occur at sites such as the pelvis, spine, skull and the metaphyseal end of a bone with simultaneous lytic lesions. Disproportionate osteoblastic activity after prolonged osteoclastic activity, the anabolic effect of parathormone on bone metabolism and high bone turnover in young age could be the mechanisms responsible for osteosclerosis. $^{23}$

\section{Learning points}

- Osteosclerosis, either focal or diffuse, is a rare radiological presentation in primary hyperparathyroidism.

- The common sites of osteosclerotic involvement in hyperparathyroidism are pelvis, spine, skull and the metaphyseal end of long bones.

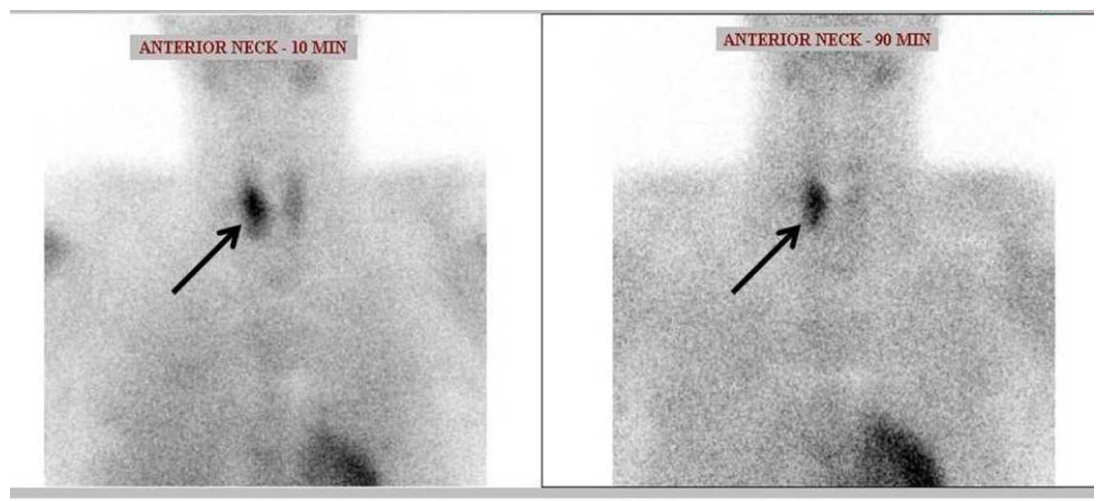

Figure 2 Parathyroid scintigraphy showing increased uptake in the right parathyroid gland. 
Contributors SS and NK managed the patient. SS, NK and DN helped in the creation of the manuscript. TVP helped in supervising the management and proof reading the manuscript before submission.

Competing interests None.

Patient consent Obtained.

Provenance and peer review Not commissioned; externally peer reviewed.

\section{REFERENCES}

1 Connor TB, Freijanes J, Stoner RE, et al. Generalized osteosclerosis in primary hyperparathyroidism. Trans Am Clin Climatol Assoc 1974;85:185-201.

2 Fujino $Y$, Inaba M, Nakatsuka $K$, et al. Primary hyperparathyroidism with multiple osteosclerotic lesions of the calvarium. J Bone Miner Res 2003;18:410-12.

3 Chopra S, Manchanda S, Kothari S, et al. Multiple osteosclerotic lesions of skull in two with co-existing hyperparathyroidism and vitamin D deficiency. JIACM 2012;13:349-51.

Copyright 2014 BMJ Publishing Group. All rights reserved. For permission to reuse any of this content visit http://group.bmj.com/group/rights-licensing/permissions.

BMJ Case Report Fellows may re-use this article for personal use and teaching without any further permission.

Become a Fellow of BMJ Case Reports today and you can:

- Submit as many cases as you like

- Enjoy fast sympathetic peer review and rapid publication of accepted articles

- Access all the published articles

- Re-use any of the published material for personal use and teaching without further permission

For information on Institutional Fellowships contact consortiasales@bmjgroup.com

Visit casereports.bmj.com for more articles like this and to become a Fellow 